\title{
ANALISIS KUALITAS KERJA PEGAWAI TATA USAHA SEKOLAH MENENGAH ATAS NEGERI 1 BENGKULU TENGAH
}

Oleh:

\author{
ARISA ARISANTI, ANTONIO IMANDA, HARIUS EKO SAPUTRA \\ Program Studi Administrasi Publik Fakultas Ilmu-Ilmu Sosial \\ Universitas Dehasen Bengkulu
}

\begin{abstract}
This study aims to find out the work quality of administrative Staff at SMAN 1of Central Bengkulu. This study uses a qualitative method. The data collection was donethrough observation, interview and documentation. The informants in this study amounted to 5 people, namely the headmaster, head of administration, teachers, administrative staff, and students. The results of this study show that the work quality of administrative staffat SMAN 1of Central Bengkulu is already good.Based on the interviews with the informants of administrative staff,the staff also have their own potential, optimal work results, work process and enthusiasm at work.
\end{abstract}

Keywords: work quality, administration

\section{PENDAHULUAN}

Dalam era globalisasi sekarang ini kinerja pegawai merupakan bagian yang sangat penting untuk suatu lembaga instansi. Pegawai dituntut untuk bekerja sungguh-sungguh sesuai dengan kemampuan yang dimiliki untuk mencapai hasil kerja yang baik, tanpa adanya kinerja yang baik dari seluruh pegawai, maka keberhasilan dalam mencapai tujuan akan sulit tercapai. Seorang pegawai atau karyawan akan merasa mempunyai kebanggaan dan kepuasan tersendiri dengan prestasi dari yang dicapai berdasarkan kinerja yang diberikannya untuk suatu instansi. Kinerja yang baik merupakan keadaan yang diinginkan dalam dunia kerja.

Kemajuan suatu organisasi sangat ditentukan dari kinerja pegawai atau karyawan dalam menjalankan tugas dan tanggung jawab yang telah diberikan. Oleh sebab itu setiap organisasi pada umunya mengharapkan para pegawai mampu melaksanakan tugasnya dengan baik. Hal ini bertujuan agar organisasi memiliki kinerja pegawai yang berkualitas dan sekaligus memiliki daya juang yang tinggi.

Menurut Mangkunegara (2009:67), kinerja (prestasi kerja) adalah suatu hasil kerja secara kualitas dan kuantitas yang dicapai oleh seseorang pegawai dalam melaksanakan tugasnya sesuai tanggung jawab yang diberikan kepadanya. Untuk mengetahui kinerja pegawai yang berkualitas dan dapat mengembangkan organisasi secara efektif dan efisien, maka perlu dilakukanpenilaian terhadap kinerja pegawai secara pribadi/individu, karena dengan penilaian kinerja tersebut dapat diketahui sebenarnya tentang kondisi pegawai tersebut. Penilaian 
kinerja adalah usaha untuk merencanakan dan mengontrol proses pekerjaan.

Berkualitas bukan hanya pandai saja, memenuhi semua syarat kualitatif yang dituntut pekerjaan itu, sehingga pekerjaan itu benar-benar dapat diselesaikan sesuai rencana. Kualitas kerja merupakan wujud perilaku dari suatu kegiatan yang telah dilaksanakan dan sesuai dengan harapan yang telah ditentukan sebelumnya. Menurut marcana (2000:21) menyebutkan bahwa yang dimaksud dengan kualitas kerja yaitu kualitas kerja adalah wujud perilaku atau kegiatan yang dilaksanakan sesuai dengan harapan dan kebutuhan atau tujuan yang hendak dicapai secara efektif dan efisien.

Pentingnya kinerja yang baik dalam sebuah instansi sangat menentukan kualitas dan kuantitas kinerja ketatausahaan, mengingat kinerja sangatlah penting untuk menata dan mengatur kelancaran proses dan ketertiban administrasi pada sebuah sekolah. Pegawai tata usaha sekolah merupakan bagian yang tak terpisahkan dari seluruh kegiatan pendidikan. Kegiatan administrasi bertujuan untuk memberikan dukungan kepada kegiatan yang bersifat akademis. Dalam peningkatan mutu disekolah peran pegawai menjadi penting dan perlu mendapatkan perhatian dari seluruh komponen yang terlibat dalam pengembangan Sekolah.

Pada saat sekarang ini, setiap instansi harus mampu melakukan efisiensi, peningkatan mutu, dan kinerja serta penataan kearsipan dengan baik dan rapi. Peningkatkan kinerja tidak lepas dari kemampuan dalam perencanaan, pengkoordinasian, dan pengendalian berbagai aktifitas sumber dayamanusia yang dimiliki. Sumber daya manusia memiliki kedudukan sentral, karena berperan dalam menentukan tingkat keefektifan dan keefesienan setiap instansi. Pada umumnya instansi pemerintah khususnya dalam dunia pendidikan memiliki tata usaha sebagai penata administrasi sekolah.
Tata usaha merupakan bagian yang berperan penting dalam pelaksanaan administrasi di sekolah, serta diperlukan untuk menunjang tercapainya tujuan pendidikan. Pegawai tata usaha memberikan layanan kepada seluruh pihak yang berkepentingan terutama dalam hal pelayanan administrasi. Pegawai tata usaha dituntut untuk dapat memberikan layanan yang bermutu untuk menunjang segala kelancaran aktivitas sekolah. Pada hakikatnya kegiatan tata usaha adalah segenap kegiatan pengelolaan suratmenyurat yang dimulai dari menghimpun (menerima), mencatat, mengelola, menggandakan, mengirim, dan menyimpan semua bahan keterangan yang diperlukan oleh organisasi.

Ada juga yang menyebutkan bahwa tata usaha adalah suatu bagian dari sekolah yang berfungsi sebagai pendukung kegiatan belajar mengajar agar berjalan lancar sesuai apa yang telah direncanakan dan bisa tercapai seperti apa yang diinginkan. Untuk mendukung semua tugas yang berjalan didalam instansi, dibutuhkan pegawai tata usaha yang mempunyai disiplin, loyalitas, dan tanggung jawab terhadap tugas-tugas mereka. Tugas dari tata usaha adalah untuk membantu proses belajar-mengajar, urusan kesiswaan, kepegawaian, peralatan sekolah, urusan insfrastuktur sekolah, keuangan, bekerja dilaboratorium, perpustakaan dan hubungan masyarakat (Husaini, 2006 : 21).

Berdasarkan Peraturan Menteri Pendidikan Nasional Republik Indonesia Nomor 24 Tahun 2008 Tentang Standar Tenaga Administrasi Sekolah, tugas tenaga administrasi sekolah dijenjang pendidikan dasar dan menengah tidak boleh dirangkap oleh tenaga fungsional yang lain. Dalam Permen tersebut juga dijelaskan bahwa standar tenaga administrasi sekolah/ madrasah mencangkup kepala tenaga administrasi, pelaksana urusan, dan petugas layanan khusus sekolah/ madrasah. Untuk dapat diangkat sebagai tenaga administrasi sekolah/ 
madrasah. Seseorang wajib memenuhi standar tenaga administrasi sekolah/madrasah yang berlaku secara nasional. Penyelenggaraan sekolah/ madrasah dapat menetapkan perangkapan jabatan tenaga administrasi pada sekolah/ madrasah yang diselenggarakannya. (Permendiknas No. 24/2008).

Suatu ketidakjelasan pembagian tugas dan tanggung jawab dari setiap staf tata usaha adalah kelemahan. kelemahannya adalah masalah tanggung jawab siapa kalau pekerjaan tidak selesai atau bermasalah. Dan juga ada ketidakjelasan perbedaan pemahama tupoksi antara guru dan Tata Usaha,sebagai awal pemicu banyak kekisruhan konflik guru dan tata usaha di sekolah. Sampai saat ini masih ada sekolah/ madrasah yang menganggap tugas guru hanya mengajar, sementara selain mengajar adalah tugas tata usaha. Fenomena tata usaha sebagai pelayan guru, juga memperkuat peluang konflik guru tata usaha. Apalagi dengan masih terbatasnya kemampuan sejumlah guru dalam menggunakan komputer menyebabkan guru "menyerahkan" semua tugas yang sebetulnya masih tupoksi nya kepada tata usaha.

Administrasi sekolah tidak hanya dilakukan dalam waktu tertentu saja tetapi setiap hari secara terus-menerus, karena itu sumber daya manusia dalam hal ini tenaga administrasi sekolah tidak bisa dipisahkan antara komponen yang satu dengan yang lain agar tujuan pendidikan dapat dicapai sesuai harapan.

Berdasarkan observasi awal yang penulis lakukan di Sekolah Menengah Atas Negeri 1 Bengkulu Tengah. Pegawai tata usaha belum adanya pembagian tugas yang jelas, karena aktifitas kerja beberapa orang pegawai tata usaha masih terlihat kurang efektif dan kurang bertanggung jawab. Sebagian pegawai hanya menunggu perintah dari Kepala Tata Usaha untuk mengerjakan tugas-tugas yang harus dikerjakan oleh mereka, dan bahkan terlihat juga beberapa orang pegawai tidak melakukan aktifitas pekerjaan sama sekali. Serta pegawai belum mempunyai rencana kerja yang konkrit dan menyeluruh.

\section{METODE PENELITIAN}

Metode penelitian yang digunakan merupakan penelitian kualitatif. Menurut Bogdan \& Taylor (dalam Ahmadi 2014 :15), Metode kualitatif adalah prosedur penelitian yang menghasilkan data deskriptif, ucapan atau tulisan dalam perilaku yang dapat diamati dari orang-orang (subjek) itu sendiri.

Menurut Wirartha (2006:135), penelitian kualitatif bersifat deskriptif karena analisa data yang dilakukan tidak untuk menerima atau menolak hipotesis, melainkan berupa deskripsi atas gejala-gejala yang diamati, yang tidak selalu harus berbentuk angka-angka atau koefisien antar variabel.

Sejalan dengan tujuan penelitian yang telah ditetapkan, maka penelitian ini bermaksud untuk mengungkap situasi atau variabel sesuai dengan keadaan yang ada pada saat penelitian itu dilaksanakan. Situasi atau keadaan yang perlu diungkap melalui penelitian ini adalah tentang Kualitas Kerja Pegawai Tata Usaha di Sekolah Menengah Atas Negeri 1 Bengkulu Tengah.

Sejalan dengan jenis penelitian yang dilakukan maka penetapan informan dalam penelitian ini menggunakan teknik purposive sampling. Dalam Sugiyono (2011 :96), teknik sampling purposive adalah teknik penentuan sampel dengan pertimbangan tertentu. Dalam penelitian ini sampel diambil berdasarkan kriteria tertentu, terutama yang mengerti permasalahan penelitian yaitu tentang kinerja pegawai tata usaha.

\section{HASIL PENELITIAN DAN PEMBAHASAN}

Metode analisis yang digunakan dalam penelitian ini adalah metode analisis data kualitatif dilakukan terus menerus secara interaktif disetiap tahap penelitian hingga selesai. Data yang disajikan peneliti dengan 
pengelompokan data secara sistematis dalam bentuk deskripsi agar mudah dipahami dalam berbagai interaksi antara bagian-bagian dalam konteks yang utuh.

Kualitas kerja adalah mutu seorang karyawan atau pegawai dalm hal melaksanakan tugas-tugasnya. Kualitas kerja juga mengacu pada kualitas sumber daya manusia seperti pengetahuan, keterampilan, dan kemampuan yang dimiliki seseorang sebagai pegawai atau karyawan. Kualitas kerja meliputi potensi diri, hasil kerja optimal, proses kerja dan antusiasme. Berikut hasil penelitian berdasarkan Grand theory, yang digunakan adalah teori menurut Hasibuan (2003 :95) yaitu :

\section{Potensi Diri}

Potensi diri merupakan kemampuan, kekuatan, baik yang belum terwujud maupun yang telah terwujud, yang dimiliki seseorang, tetapi belum sepenuhnya terlihat atau dipergunakan secara maksimal. Dalam konteks kualitas kerja pegawai tata usaha sekolah. Pegawai tata usaha di SMA Negeri 1 Bengkulu Tengah sudah memiliki pengetahuan tentang administrasi. Administrasi yang ada di SMA Negeri 1 Bengkulu Tengah yaitu administrasi kepegawaian, administrasi kesiswaan, dan administrasi arsiparis/ inventaris. Meski pegawai tata usaha di SMA Negeri 1 Bengkulu Tengah sudah memiliki pengetahuan tentang administrasi, baik administrasi kepegawaian, administrasi kesiswaan, dan administrasi arsiparis/ inventaris, pengetahuan yang dimiliki belum mendalam, karena masih ada pegawai yang belum tepat waktu. Hal tersebut juga dipengaruhi oleh tingkat pendidikan dan pengalaman yang dimiliki seseorang berdampak terhadap kemampuannya dalam bekerja.

Selain itu juga sangat berdampak dengan hasil yang dikerjaan seorang pegawai. contohnya kalau tidak sesuai dengan SOP maka pekerjaan terbengkalai/ tidak tepat waktu dan tidak efektif dalam bekerja. Berdasarkan tingkat pendidikan pegawai tata usaha SMA Negeri 1 Bengkulu Tengah dari bidang ilmu yang dimiliki tidak berpotensi dalam bidang administrasi. Oleh karena itu pegawai diberikan pelatihan kepegawaian agar pegawai tata usaha yang bukan jurusan administrasi juga mengerti tentang administrasi sesuai dengan bidang pekerjaan.

\section{Hasil Kerja Optimal}

Hasil kerja yang optimal harus dimiliki oleh seorang pegawai, pegawai harus bisa memberikan hasil yang terbaik, salah satunya dapat dilihat dari produktivitas organisasi, kualitas kerja, kuantitas kerja. Adapun hasil pengamatan peneliti dengan informan tentang kualitas kerja. Apakah pegawai tata usaha saat ini dapat menyelesaikan tugas administrasi urusan kesiswaan yang menjadi tanggung jawabnya.

Bisa dilihat pegawai tata usaha administrasi kesiswaan dapat menyelesaikan tugas yang menjadi tanggung jawabnya. Pegawai selalu menyelesaikan tugasnya mulai dari pengumpulan data kesiswaan yang akan dimasukkan ke dalam buku induk, ataupun untuk urusan mutasi siswa. Tugas administrasi urusan kesiswaan yang juga menjadi tanggung jawabnya, mampu mereka kerjakan dengan disiplin dan tepat waktu.

\section{Proses Kerja}

Proses kerja merupakan suatu tahapan terpenting dimana pegawai menjalankan tugas dan perannya dalam suatu organisasi, melalui proses kerja ini kinerja pegawai dapat dilihat dari kemampuan membuatperencanaan kerja, kreatif dalam melaksanakan pekerjaan, mengevaluasi tindakan perbaikan. Pekerjaan yang dilakukan oleh para pegawai tata usaha selalu dalam pengawasan Kepala Tata Usaha tetapi hasil dari pekerjanya selalu dilihat oleh kepala sekolah. Jika terjadi kesalahan didalam pekerjaan yang dilakukan olehpegawai tata usaha, maka akan diberikan teguran dan diberitahu ini salah serta arahan bagi pegawai yang melakukannya.pengawasan atau kontrol 
terhadap pegawai tata usaha yang sedang bekerja adalah tugas dari kepala tata usaha, namun semua hasil kerja yang dikerjakan para pegawai tata usaha dilihat oleh kepala sekolah. Dan seandainya pegawai tata usaha yang telah melaksanakan suatu pekerjaan mengalami kesalahan maka akan dipanggil dan ditegur bahwa yang dikerjakan salah, dan diberitahu bahwa yang benarnya seperti apa. Dan apabila kesalahan para pegawai ada yang tidak disiplin maka akan ada SP (Surat Panggilan) untuk pegawai tata usaha di SMA Negeri 1 Bengkulu Tengah. Peneliti melihat bahwa pegawai tata usaha yang ada di SMA Negeri 1 Bengkulu tengah inisiatif, inisiatif disini dilihat dari pegawai yang apabila diberikan tugas segera mengerjakannya dan tidak menunda-nunda pekerjaan tersebut.

\section{Antusiasme}

Antusiasme merupakan suatu sikap dimana seorang pegawai melakukan kepedulian terhadap pekerjaannya hal ini bisa dilihat dari kehadiran, pelaksanaan tugas, motivasi kerja, komitmen kerja. Pegawai Tata Usaha disekolah ini terlihat bersemangat dalam mengerjakan tugas- tugasnya.pegawai tata usaha di SMA Negeri 1 Bengkulu Tengah sangat bersemangat dalam menjalankan tugas administrasi, baik administrasi kepegawaian, administrasi kesiswaan dan administrasi arsiparis/inventaris.Selanjutnya apabila ada pekerjaan yang cukup banyak dan harus diselesaikan dengan cepat, dapatkah mereka mengerjakannya sesuai dengan target waktu yang direncanakan. Pegawai tata usaha dapat menyelesaikanpekerjaan dalam target waktu yang singkat, para pegawai dikumpulkan dan diberi arahan dari kepala tata usaha tentang pembagian tugas agar dapat diselesaikan dengan target waktu yang direncanakan, para pegawai tata usaha saling bahu-membahu. Pegawai tata usaha memiliki antusiasme tinggi, dibuktikan kehadiran yang baik, cepat melaksanakan tugas karena memiliki motivasi dan komitmen yang tinggi.
Berdasarkan hasil penelitian kerja pegawai tata usaha SMA Negeri 1 Bengkulu tengah berkualitas baik. Hal ini dibuktikan dengan hasil wawancara, observasi dan dokumentasi bahwa dari tingkat pendidikan kurang berpotensi karena latar belakang pendidikan tidak sesuai. Namun pegawai telah diberikan pelatihan terkait dengan bidang pekerjaan masing- masing.

Hasil pekerjaan pegawai tata usaha SMA Negeri 1 bengkulu tengah optimal. Pegawai tata usaha SMA Negeri 1 Bengkulu tengah tepat waktu, dilihat dari semua pekerjaan seperti administrasi urusan kepegawaian, administrasi urusan kesiswaan, dan administrasi urusan arsiparis/ inventaris dikerjakan dengan cepat dan disiplin waktu. Disaat diberi tugas pegawai tata usaha langsung mengerjakannya dan tidak menunda-nunda pekerjaan tersebut. Dalam proses kerjapun pegawai tata usaha peneliti melihat bahwa pegawai tata usaha yang ada di SMA Negeri 1 Bengkulu tengah inisiatif, inisiatif disini dilihat dari pegawai yang apabila diberikan tugas segera mengerjakannya.

Proses kerja pegawai tata usaha SMA Negeri 1 Bengkulu tengah dapat disimpulkan bahwa setiap pegawai memiliki perencanaan kerja dan memiliki inisiatif dalam menjalankan tugas serta adanya evaluasi tindakan perbaikan dari kepala sekolah dan kepala tata usaha apabila ada pekerjaan yang salah. Tindakan perbaikan biasanya langsung saat pekerjaan yang diselesaikan oleh pegawai tata usaha SMA Negeri 1 Bengkulu Tengah dilihat oleh kepala sekolah dan kepala tata usaha. Pegawai tata usaha SMA Negeri 1 Bengkulu Tengah memiliki antusiasme yang tinggi.

Antusiasme pegawai tata usaha SMA Negeri 1 Bengkulu Tengah yang tinggi dibuktikan dengan kehadiran yang baik dimana datang dan pulang sesuai jam kerja, cepat melaksanakan tugas apabila ada yang memberikan tugas, pegawai tata usaha SMA 
Negeri 1 Bengkulu Tengah langsung mengerjakannya dan tidak menunda-nunda, Mereka memiliki motivasi dan komitmen yang tinggi.

\section{PENUTUP}

\section{Kesimpulan}

Berdasarkan hasil penelitian dan pembahasan Kualitas Kerja Pegawai Tata Usaha SMA Negeri 1 Bengkulu Tengah berkualitas baik. Didasarkan teori menurut Hasibuan (2003 :95) dapat dijelaskan sebagai berikut:

1. Potensi diri yang dimiliki pegawai tata usaha SMA Negeri 1 Bengkulu dalam tingkat pendidikan kurang berpotensi karena latar belakang pendidikan tidak sesuai. Namun pegawai tata usaha SMA Negeri 1 Bengkulu Tengah telah diberikan pelatihan terkait dengan bidang pekerjaan masing-masing.

2. Hasil kerja Pegawai tata usaha SMA Negeri 1 Bengkulu tengah Optimal, dilihat dari semua pekerjaan seperti administrasi urusan kepegawaian, administrasi urusan kesiswaan, dan administrasi urusan arsiparis/inventaris dikerjakan dengan cepat dan disiplin waktu. Disaat diberi tugas pegawai tata usaha SMA Negeri 1 Bengkulu Tengah langsung mengerjakannya dan tidak menunda-nunda.

3. Proses kerja pegawai tata usaha SMA Negeri 1 Bengkulu tengah setiap pegawai memiliki perencanaan kerja dan memiliki inisiatif dalam menjalankan tugas serta adanya evaluasi tindakan perbaikan dari kepala sekolah dan kepala tata usaha apabila ada pekerjaan yang salah.

4. Pegawai tata usaha SMA Negeri 1 Bengkulu Tengah memiliki Antusiasme yang tinggi, Antusiasme yang tinggi dibuktikan dengan kehadiran yang baik dimana datang dan pulang sesuai jam kerja, cepat melaksanakan tugas apabila ada yang memberikan tugas, pegawai tata usaha SMA Negeri 1 Bengkulu Tengah langsung mengerjakannya dan tidak menunda-nunda, Mereka memiliki motivasi dan komitmen yang tinggi.

\section{Saran}

Berdasarkan hasil kesimpulan penelitian diatas peneliti menyarankan, yaitu apabila ingin rekrutment pegawai tata usaha jangan melihat latar belakang pendidikan S1 saja, namun hendaknya melihat juga bidang ilmu atau jurusan yang dimiliki pegawai tata usaha. Yang seperti pegawai tata usaha hendaknya berpendidikan S1 bidang Administrasi agar pegawai tata usaha mengerti akan tentang pengadministrasian yang ada ditata usaha.

\section{DAFTAR PUSTAKA}

Afandi, Pandi. 2018. Manajemen Sumber Daya Manusia; Teori, Konsep dan Indikator. Yogyakarta, Zafana Publishing, Nusa Media

Ahmadi, Rulam. 2014. Metode Penelitian Kualitatif. Yogyakarta, Ar-Ruzz Media

Desseler, Gary. 2009. Manajemen Sumber Daya Manusia Edisi 9. Yogyakarta, Andi Offset

Gie, The Liang. 2007. Administrasi Perkantoran Modern Edisi Keempat. Yogyakarta, Liberty

Husaini, Usman. 2006. Manajemen Teori, Praktik dan Riset Pendidikan. Jakarta, PT. Bumi Aksara.

Hasibuan, Malayu. 2003. Manajemen Dasar, Pengertian, dan Masalah. Jakarta, Bumi Aksara.

James A.F. Stoner, Freeman, Gilbert. 1996. Manajemen: alih bahasa Alexander Sindoro. Jakarta, PT. Prenhallindo

Pusat Bahasa Departemen Pendidikan Nasional. 2007. Kamus Besar Bahasa Indonesia. Jakarta, Balai Pustaka

Mangkunegara, Anwar Prabu. 2009. Manajemen Sumber Daya Manusia Perusahaan. Jakarta, Rosdakarya 
Syafri, H. Wirman. Studi Tentang Administrasi Public. Suripto, PT. Gelora Aksara Pratama

Sugiyono. 2011. Metode Penelitian kualitatif: Bandung, Alphabet

Suripto, Chabib Soleh. Menilai Kinerja Pemerintahan Daerah. Bandung, Fokus Media
Sutrisno Edi, 2010. Budaya Organisasi, Jakarta, Kencana.

Singarimbun, Masri dan Sofian Effendi. 1991. Metode Penelitian Survei. Jakarta, LP3ES Wahyuni, Sri Niniek, 2005. Sosiologi Manusia dan Masyarakat. Bandung, Ganeca Exact 